\title{
MJERNI INSTRUMENT ZA UTVRĐIVANJE STUPNJA RAZVIJENOSTI ZAŠTITE ZDRAVLJA I SIGURNOSTI NA RADU
}

UDK 331.48:681.2.087

PRIMLJENO: 25.7.2017.

PRIHVAĆENO: 22.2.2018

\begin{abstract}
SAŽETAK: Sustav zaštite zdravlja i sigurnosti na radu potrebno je planirati, organizirati, voditi te nadzirati kako bi ga se učinkovitije usmjerilo prema željenoj viziji potpunog izostanka ozljeda i zdravstvenih problema nastalih na radu. Cilj rada je predstaviti koncept i provjera cjelovitoga mjernog instrumenta za utvrđivanje stupnja razvijenosti zaštite zdravlja i sigurnosti na radu (ZZSR) u organizaciji. Opisanim mjernim instrumentom u tome empirijskome istraživanju utvrđena je razvijenost ZZSR-a u 137 slovenskih velikih i srednje velikih poduzeća. Mjerni instrument omogućuje cjelovito proučavanje međusobnih poveznica između menadžmenta ZZSR-a, radnih uvjeta i ekonomske učinkovitosti organizacije. Važan je zaključak istraživanja da je područje izvođenja funkcija menadžmenta ZZSR-a moguće proučavati iz triju perspektiva: perspektive organiziranosti funkcija menadžmenta ZZSR-a, perspektive dokumentiranosti postupaka i perspektive redovitoga praćenja izvođenja mjera ZZSR-a. Mjerni instrument izvorno je i korisno pomagalo kako za kreatore politike ZZSR-a u određenoj državi, vlasnike i menadžere, zaposlene i njihove zastupnike, tako i za stručnjake za ZZSR u poduzeću ili drugoj ustanovi.
\end{abstract}

Ključne riječi: instrument, istraživanje, menadžment, mjerenje, poduzeća, razvijenost, zaštita zdravlja i sigurnost na radu

\section{UVOD}

U posljednjih nekoliko desetljeća u državama, regijama i poduzećima te u drugim organizacijama postoji sve veće zanimanje za nezgode na radu, a među razlozima za to svakako su troškovi nastali zbog tih nezgoda (Hämäläinen et al., 2009., Jeffries, 2011.). U svjetskome mjerilu ozljede na radu i bolesti u vezi s radom godišnje uzrokuju više od 2.300.000 smrtnih slučajeva, od kojih je približno 300.000 posljedica ozljeda

*Dr. sc. Borut Kodrič, (borut.kodric@fm-kp.si), dr. sc. Mirko Markič, (mirko.markic@fm-kp.si), Univerza na Primorskem, Fakultetaza management, Cankarjeva 5, 6000 Koper, Slovenija, prof. dr. sc. Alenka Pavlič, (alenka.pavlic@mf.uni-lj.si), Univerza v Ljubljani, Medicinska fakulteta, Hrvatski trg 6, 1000 Ljubljana, Slovenija, dr. sc. Miran Pavlič, (miran.pavlic@kclj.si), Univerzitetni klinični center Ljubljana, Zaloška 2, 1000 Ljubljana, Slovenija. na radu, a 2.000.000 posljedica bolesti u vezi s radom (Takala et al., 2009., 2014.). U europskim državama ekonomski troškovi zbog ozljeda na radu i bolesti u vezi s radom iznose prosječno $4 \%$ BDP-a, a pritom se procjene po pojedinačnim državama kreću između 1,8 \% i 6 \% BDPa (WSHI, 2014.). Unatoč osjetnomu smanjenju broja nezgoda i boljoj preventivi, na području zaštite zdravlja i sigurnosti na radu u EU-u i dalje su potrebna poboljšanja (EASHW, 2014.). U skladu s navedenim, zanimanje za ekonomske perspektive zaštite zdravlja i sigurnosti na radu (ZZSR) raste (Ahonen \& Hussi, 2012.).

Europska agencija za ZZSR tako ističe važnost priznavanja zaštite zdravlja i sigurnosti na radnome mjestu za poboljšanje radnih uvjeta te povećanje učinkovitosti. U skladu s ciljevima 
strateškoga okvira EU-a za ZZSR za razdoblje od 2014. do 2020. i strategije Europa 2020. za stvaranje pametnoga, trajnoga i uključujućega europskoga gospodarstva Europska agencija za ZZSR ujedno ističe i važnost samoga istraživanja ZZSR-a. Kreatori politika i istraživači ZZSRa moraju naime imati na raspolaganju sigurne i pouzdane podatke te činjenice (EAVZD, 2014.).

O važnosti istraživanja ZZSR-a govore i rezultati cijeloga niza istraživanja (Duijm et al., 2008., Fernandez-Muniz et al., 2009., Yien et al., 2011., Buhai et al., 2013.), u sklopu kojih autori primjećuju manjak empirijskih istraživanja koja bi povezivala kvalitetu radnoga okruženja odnosno radnih uvjeta s poslovnom učinkovitošću. Navode da u stručnoj literaturi nije moguće pronaći jednoznačan odgovor na pitanje o tome vode li sigurnija radna mjesta većemu učinku, sa čime se slažu i autori ovoga članka.

S neuređenim radnim uvjetima, koji se zrcale u ozljedama na radu, bolestima u vezi s radom te, posredno, troškovima, povezan je niz čimbenika. Ovaj rad ograničava se samo na jedan od najvažnijih, a to je menadžment ZZSR-a. Kvalitetan menadžment je, naime, prvi i najvažniji čimbenik koji utječe na uspješnost poduzeća ili druge organizacije (De Waal, 2008.). Organizacijski čimbenici, poput potpore menadžmenta, organizacijske kulture i klime, potpore nadređenih, obvezatnost menadžerâ sigurnosti, statusa ZZSR-a u organizaciji itd., od 1970. godine prepoznati su kao važni uzročni čimbenici za pojavljivanje ozljeda i zdravstvenih problema (Doidge, 1997., Vivek et al., 2012.).

Menadžment ZZSR-a trebao bi biti oblikovan u skladu s općim aktima (npr. sa statutom, pravilnicima, odredbama itd.) organizacije za menadžment prirodnoga okruženja i menadžmenta cjelovite kvalitete tako da se izbjegnu mogućnosti konfliktnih svrha i ciljeva za suradnike. Nadalje, menadžment ZZSR-a uključuje brojna tehničko-tehnološka, pravna, zdravstvena, kadrovska i organizacijska područja djelovanja. Ukupni, odnosno sustavni pristup, koji bi trebao uključivati što je više moguće perspektiva sudjelovanja, trebao bi donositi brojne prednosti za društvo kao cjelinu (EC, 2009.). Riječ je o druš- tvenoj odgovornosti i uzimanju u obzir uzajamne ovisnosti sudionikâ kao putu do cjelovitosti i posljedično do uspjeha u praksi (Šarotar Žižek \& Mulej, 2016.).

U skladu s izloženim spoznajama, autori se slažu s tvrdnjama koje donose Duijm i suradnici (2008.). Oni konstatiraju da bi model menadžmenta na području ZZSR-a te menadžmenta prirodnoga okruženja mnogo dobio sa smjernicama kako ih učinkovito upotrebljavati. Jedan od mogućih i priznatih izazova za kontinuirano preventivno svladavanje ZZSR-a trebao bi biti i u traženju načinâ za pravovremeno primjećivanje signalâ s pomoću različitih indikatora o trenutnome stanju s kojima bi ga bilo moguće bolje svladati (Uien et al., 2011.).

S tim ciljem autori su razvili mjerni instrument, sastavljen i iskušan na temelju teorijskoga i praktičnoga koncepta o ZZSR-u koji bi bio učinkovito oruđe pri procjenjivanju razvijenosti ZZSR-a. Konceptualni okvir predstavljale su temeljne funkcije menadžmenta: planiranje, organiziranje, vođenje i kontroliranje zaštite zdravlja na radu. Ispunjavanje osnovnih zakonom određenih sigurnosnih mjera proizlazilo je iz sadržaja Europske direktive 89/391/EEZ o poticanju mjera za poboljšanje zaštite zdravlja na radu te slovenskoga Zakona o varnosti in zdravju pri delu (Zakona o sigurnosti i zdravlju na radu); (Kalčič \& Lozar, 2011.).

\section{TEORIJSKA POLAZIŠTA I KONCEPTUALNI OKVIR}

Europska uredba 1338/2008 za vođenje statistike o ozljedama na radu, profesionalnim bolestima i bolestima u vezi s radom definira ZZSR kao sve čimbenike povezane s preventivom, zaštitom zdravlja i zaštitom djelatnika na radu u sklopu njihovih sadašnjih ili prošlih djelatnosti, osobito u vezi s nezgodama na radu, profesionalnim bolestima i s drugim zdravstvenim tegobama i problemima povezanima s radom $(E U, 2008$.).

Zbog kompleksnosti problematike osiguravanje ZZSR-a zahtijeva multidisciplinaran pristup, koji uključuje tehničke, zdravstvene, socijalne, 
odgojne, pravne i druge zaštitne mjere, kao što su organizacijske, obrazovne, ekonomske, ergonomske, sanitarne i druge mjere te procesi koje sadrži cjelovit menadžment ZZSR-a (v. ZVZD br. 56/99., 64/01. i 43/11., Markič, 1993., EC, 2009.).

U Europskoj komisiji (EC, 2009.) ističe se potreba za sustavnim pristupom koji uključuje što je više moguće navedenih perspektiva sudjelovanja, pri čemu je na temelju niza radova (Krause, 2004. De Greef \& Van den Broek, 2004., Huang et al., 2007., Duijm et al., 2008.) moguće donijeti zaključke o donekle umanjenoj važnosti tradicionalnih tehničko-tehnoloških preventivnih aktivnosti te o težištu na drugim načinima postupanja, kao što je menadžment ZZSR-a. Baš kao FernandezMuniz i sur. (2009.) ili EASHW (2012.), i autori drugih istraživanja (Robson et al., 2007., Buhai et al., 2013., Podgorski, 2015.) ističu učinkovitost menadžmenta ZZSR-a kao jedan od ključnih čimbenika za učinkovito oblikovanje i održavanje sigurnoga i zdravoga radnog okruženja.

S obzirom na istaknuto opadanje važnosti tradicionalnih tehničko-tehnoloških preventivnih aktivnosti te naglašavanje drugih načina postupanja pri oblikovanju te održavanju sigurnoga i zdravoga radnog okruženja, i ovaj se razvijen instrument za mjerenje razvijenosti područja ZZSR-a nadovezuje prvenstveno na uređenost sustava menadžmenta ZZSR-a. S time u vezi valja istaknuti da je pri oblikovanju/stvaranju mjernoga instrumenta uzeta u obzir i perspektiva menadžmenta ZZSR-a kao procesa odnosno spleta različitih funkcija, kao i perspektiva ključnih aktivnosti menadžmenta ZZSR-a:

- Proces menadžmenta ZZSR-a odnosi se na niz međusobno povezanih funkcija, pri čemu se kao temeljne ističu funkcija planiranja, organiziranja, vođenja i kontroliranja svih raspoloživih izvora s namjerom dosezanja svrha i ciljeva organizacije (Fayol, 1949., Drucker, 1955., Bernard, 2001.).

- Među djelatnostima odnosno aktivnostima menadžmenta ZZSR-a posebna pozornost posvećena je aktivnostima informiranja, odlučivanja te upravljanja ljudskim resursima. Pritom su autori u obzir uzeli rezultate koje u svojim radovima navode Milgate i sur. (2002.), Morse i sur. (2013.), te Yassi i sur. (2013.). U njima su autori proučavali važnost i učinkovitost odborâ za ZZSR u poduzećima pri svladavanju menadžmenta ZZSR-a i izvođenju mjera za osiguravanje ZZSR-a. O važnome utjecaju međusobnoga sudjelovanja vodstava poduzećâ na jednoj strani te službi ZZSRa odnosno stručnjaka za ZZSR na drugoj strani te o učinkovitosti osiguravanja ZZSR-a moguće je pak zaključivati na temelju rezultatâ istraživanja koje su proveli Markič i sur. (2011.), Jarle i sur. (2012.) te Thanwadee (2012.) koji utvrđuju da odnos top menadžera prema sigurnosti i zdravlju pozitivno utječe na vođenje te da aktivno sudjelovanje top menadžera izrazito pozitivno utječe na zaposlene te na ishode na području ZZSR-a.

Uz izložena teorijska polazišta s područja menadžmenta pri oblikovanju mjernoga instrumenta autori su uzeli u obzir i pravno-formalni okvir koji se manifestira u sljedećim dvama oblicima:

- Europska direktiva 89/391/EEZ o poticanju mjera za poboljšanje zaštite zdravlja i sigurnosti na radu te

- slovenski Zakon o varnosti in zdravju pri delu (Zakon o sigurnosti i zdravlju na radu); (Kalčič \& Lozar, 2011.).

\section{METODA ISTRAŽIVANJA}

U sklopu ovoga poglavlja najprije se predstavlja operacionalizacija proučavanih kategorija, odnosno detaljnije tumači sama struktura upitnika kao predložak mjernoga instrumenta za praćenje razvijenosti sustava menadžmenta ZZSR-a. U nastavku se objašnjava i postupak empirijske provjere konstruktne valjanosti te pouzdanosti predloženoga upitnika.

\section{Operacionalizacija proučavanih kategorija}

Uzimajući u obzir konceptualni te pravno-formalni okvir predstavljen u prethodnome poglavlju, upitnik je oblikovan od sljedećih cjelina: 
- uvedenost standardâ povezanih s područjem ZZSR-a (6 pokazatelja)

- organiziranost područja ZZSR-a (način organiziranja službe za ZZSR - 4 pokazatelja, razina uklopljenosti interne službe za ZZSR - 4 pokazatelja, učestalost komunikacije s vodstvom i starost postojećega menadžmenta ZZSR-a - 5 pokazatelja)

- dosljednost izvođenja temeljnih funkcija menadžmenta ZZSR-a (planiranje - 5 pokazatelja, organiziranje - 27 pokazatelja, vođenje - 7 pokazatelja i kontroliranje 16 pokazatelja) te

- demografske značajke poduzeća (djelatnost poduzeća, sjedište poduzeća - regija, veličina poduzeća i starost poduzeća).

Pitanja su u svim navedenim cjelinama bila oblikovana kao pitanja zatvorenoga tipa. Odgovori na pitanja povezana s dosljednošću izvođenja temeljnih funkcija menadžmenta ZZSR-a bili su predviđeni u obliku 11-stupanjske ljestvice kojom se može izraziti stupanj dosljednosti izvođenja (0-100 \%) određene funkcije. U slučaju ostalih pitanja ljestvica je bila prilagođena sadržaju pojedinačne cjeline, odnosno sadržaju pitanjâ (ljestvice nominalnoga odnosno ordinalnoga tipa).

Pri oblikovanju pitanja, uz već izložena konceptualna i pravno-formalna polazišta, autori su uzeli u obzir i neke preporuke koje donose pojedini autori (Gallagher et al., 2001., Greigle, 2005., Finlan \& Roberts, 2013.) koji su, baveći se istraživanjem slične problematike, posebice isticali nužnost što točnijega i temeljitijega oblikovanja pitanjâ te odgovarajuće raščlanjenosti upotrijebljenih ljestvica. To, naime, omogućuje da proučavana populacija uzme u obzir očito prisutnu heterogenost.

\section{Postupak empirijske provjere konstruktne valjanosti i pouzdanosti mjernoga instrumenta}

Prvu provjeru jasnosti, razumljivosti i sadržajne primjerenosti oblikovanih pitanja proveli su autori uz pomoć 13 stručnjaka s područja
ZZSR-a u javnim zavodima, javnoj upravi, vojsci i policiji. Na temelju njihovih povratnih informacija odnosno prijedloga smisleno su dopunili odnosno popravili radnu inačicu upitnika.

S ciljem provjere same konstruktne valjanosti i pouzdanosti razvijenoga upitnika u nastavku je najprije provedena internetska anketa u koju su bili uključeni stručnjaci za područje ZZSR-a iz 1.300 srednje velikih i velikih tvrtki (od toga 220 velikih, s 250 ili više zaposlenih, i 1.080 srednje velikih poduzeća, koja imaju od 50 do 249 zaposlenih). Njihove elektroničke adrese preuzete su iz poslovnoga imenika Bizi.si, elektroničkoga telefonskog imenika Slovenije (TIS), Poslovnoga informatora Republike Slovenije (PIRS), s internetskih stranica poslovnoga subjekta, a dio adresa autori su dobili tijekom neposrednoga kontakta s poduzećem.

Svim izabranim poslovnim subjektima (1.300 njih) u studenome 2013. godine poslane su elektroničke poruke s pozivom na sudjelovanje u istraživanju i poveznicom na internetsku anketu. Poruka je bila naslovljena na stručnjaka odnosno službu za ZZSR s obzirom na to da najbolje poznaju sustav ZZSR-a i radne uvjete u samome poduzeću (Heinrich, 1959., Fernandez-Muniz et al., 2009.).

Dobiveni podatci analizirani su s pomoću izabranih metoda statističke analize koje su predstavljene u nastavku.

\section{STATISTIČKE METODE}

Statistička analiza podataka provedena je s pomoću programa IBM SPSS Statistics Version 24, za čiju upotrebu Univerza na Primorskem ima licenciju.

Dobiveni podatci analizirani su s pomoću izabranih metoda opisne statistike te faktorske analize, čiji je cilj određenje manjega broja ukupnih čimbenika koji najbolje objašnjavaju poveznice između promatranih varijabli, što ujedno omogućuje otkriće ukupnoga opsega promatranih varijabli te provjeru konstruktne 
valjanosti promatranoga konstrukta. Rezultati eksploratorne (objašnjavajuće) faktorske analize istovremeno su provjereni konfirmatornom (potvrđujućom) faktorskom analizom, odnosno strukturnim modeliranjem, pri čemu su u obzir uzeti sljedeći preporučeni kriteriji (Schumacker \& Lomax, 2004.):

- primjerenost modela kao cjeline ispitana je na temelju izabranih pokazatelja odgovaranja teorijskoga modela stvarnim promatranim vrijednostima

- provjerena je statistička relevantnost pojedinačnih parametara povezanosti između kategorija strukturnoga modela te

- provjerena je podudarnost ocijenjene jakosti/ocijenjenoga smjera promatranih poveznica s teorijskim pretpostavkama.

Primjerenost modela kao cjeline autori su provjerili na temelju hi-kvadrat testa (engl. chisquare test) koji je jedini test statističke relevantnosti teorijskoga modela te je kao takav jedna od najčešće korištenih metoda procjenjivanja podudarnosti teorijskoga modela i stvarnih poveznica između proučavanih kategorija (Schumacker \& Lomax, 2004.). Svjesni osjetljivosti hi-kvadrat testa na veličinu uzorka autori su pozornost obratili i na kvadratni korijen srednje kvadratne pogreške aproksimacije (engl. root mean square error of approximation - RMSEA), gdje vrijednost pokazatelja manja od 0,06, odnosno 0,08 upućuje na primjerenost modela.

Pouzdanost razvijenog mjernog instrumenta provjerena je na temelju Cronbachovog $\alpha$ koeficijenta pouzdanosti (Cronbach, 1951.) za koji bi preporučena vrijednost trebala iznositi između 0,6 i 0,8 .

\section{REZULTATI}

Upitnici, odnosno mjerni instrument za evaluaciju izvođenja mjera ZZSR-a poslani su na 1.300 elektroničkih adresa tvrtki, a kao povratnu informaciju autori su primili 137 ispunjenih upitnika, što predstavlja 10,54-postotni odaziv.
Najveći udio uzorka po NACE klasifikaciji djelatnosti, dobru polovicu, činila su poduzeća s područja prerađivačkih djelatnosti $(C=54,9 \%)$, slijedila su poduzeća s područja uslužnih i drugih djelatnosti ( do $S=10,5 \%$ ), trgovine, održavanja i popravka motornih vozila $(\mathrm{G}=7,4 \%)$ te prometa i skladištenja $(\mathrm{H}=7,2 \%)$, dok ih je najmanje bilo s područja rudarstva $(B=0,8 \%)$, poljoprivrede, šumarstva i ribarstva $(A=2,3 \%)$ te ugostiteljstva $(I=3 \%)$. Više od polovice tvrtki iz uzorka posluje već više od 50 godina, dok je poduzeća s manje od deset godina poslovanja bilo svega $6 \%$.

Među proučenim tvrtkama je osam od deset njih imalo uveden standard kvalitete ISO 9001, dobra polovica tvrtki imala je uveden sustav zaštite okoliša prema standardu ISO 14001, a trećina sustav ZZSR-a prema standardu OHSAS 18001. Dva poduzeća imala su uveden sustav ISO 26000 o društvenoj odgovornosti.

Gotovo dvije trećine tvrtki u uzorku imalo je organiziranu internu službu za ZZSR, dok je $36,5 \%$ tvrtki zadatke organiziranja i osiguravanja ZZSR-a povjerilo vanjskoj stručnoj službi. U sedam od deset poduzeća (70,8 \%) zadatke zaštite zdravlja na radu izvodi pružatelj usluga iz područja medicine rada. Donekle iznenađuje činjenica da taj postotak nije viši jer je uz ZZSR poslodavac prema slovenskome zakonodavstvu dužan osigurati (i) izvođenje zaštite zdravlja na radu.

Među poduzećima koja su imala organiziranu internu službu za ZZSR (87) u 43,8 \% slučajeva služba za ZZSR organizirana je na drugoj razini vođenja (neposredno ispod upravitelja), $27,5 \%$ poduzeća imalo je internu službu za ZZSR postavljenu na prvoj razini vođenja (neposredno ispod uprave), dok ih je najmanje, tj. $1,5 \%$, organizirano na četvrtoj razini vođenja, tj. unutar neke organizacijske jedinice, npr. odjela, sektora, referata itd.

Sedam od deset stručnjaka za ZZSR komunicira s vodstvom poduzeća barem jednom mjesečno: 43,1 \% njih komunicira s vodstvom na 
tjednoj razini, a 30,7 \% na mjesečnoj. Jedanput godišnje stručnjaci za ZZSR komuniciraju s vodstvom u 3,6 \% slučajeva, a njih gotovo $3 \%$ ne komunicira nikada.

Na temelju analize dosljednosti izvođenja temeljnih funkcija menadžmenta ZZSR-a moguće je zaključiti da se u slovenskim srednje velikim i velikim poduzećima one izvode u prosjeku od $80 \%$ do $90 \%$ slučajeva te da poduzeća koja su sudjelovala u istraživanju u $10 \%$ do $20 \%$ slučajeva ne izvode minimalne, odnosno zakonom propisane mjere. Najveći stupanj (89,2%) ispunjavanja zahtjeva bilo je moguće utvrditi na području funkcije organiziranja menadžmenta ZZSR-a (prijavljivanje nezgoda na radu, teorijsko osposobljavanje radnikâ), a najmanji (80,5 \%) na području funkcije planiranja (u vezi s planiranjem promidžbe zdravlja na radnome mjestu).

\section{Analiza funkcija menadžmenta ZZSR-a kao višedimenzijskoga konstrukta}

S obzirom na razmjerno velik broj aktivnosti u sklopu prikazanih funkcija menadžmenta sigurnosne politike i s tim povezanoga velikog broja pokazatelja, na tome su području, s ciljem dobivanja jasnije, odnosno preglednije slike čimbenika menadžmenta sigurnosne politike, sve pokazatelje iz već predstavljenih četiriju cjelina funkcija sigurnosne politike analizirali s pomoću faktorske analize.

$U$ ishodišni faktorski model autori su uključili svih 55 pokazatelja za koje je vrijednost Kaiser-Meyer-Olkinova (KMO) pokazatelja iznosila 0,710 i time upućivala na razmjerno snažan utjecaj ukupnih čimbenika na promatrane pokazatelje. Jednako tako, većina procjena komunaliteta premašivala je vrijednost 0,5 , što je odraz činjenice da utjecaj ukupnih čimbenika na procjenjivane elemente menadžmenta sigurnosne politike uglavnom prevladava nad utjecajem specifičnih čimbenika.

U sljedećim koracima model se mijenjao, pri čemu su autori smisleno uzimali u obzir eksplanatornu snagu izabranih čimbenika, aktualne procjene komunaliteta za promatrane pokazatelje i sadržajnu smislenost dobivenoga faktorskog rješenja. Od ukupno 55 pokazatelja uključenih u ishodišni faktorski model u konačnom modelu zadržano je njih 11 (Tablica 1). Povećana vrijednost KMO pokazatelja $(0,869$ u usporedbi s prvotnom vrijednosti 0,710 ), kao i procjene komunaliteta, koje su iznosile između 0,470 i 0,803, potvrđuju primjerenost skupa pokazatelja uključenih u konačnome modelu (Tablica 1).

Na temelju rotiranih ocjena faktorskih težina (upotrijebljena je bila „oblimin” metoda rotacije faktorskih težina), prikazanih u Tablici 1, moguće je razabrati da je područje izvođenja funkcija menadžmenta ZZSR-a moguće promatrati iz sljedećih triju perspektiva:

- perspektive organiziranosti funkcija menadžmenta ZZSR-a (7 pokazatelja)

- perspektive dokumentiranosti postupaka povezanih sa ZZSR-om (2 pokazatelja) te

- perspektive redovitoga praćenja izvođenja mjera ZZSR-a (2 pokazatelja).

S pomoću definiranih triju perspektiva moguće je objasniti dobrih $62 \%$ cjelokupne varijabilnosti uzorka, pri čemu je najvažnija perspektiva organiziranosti koja objašnjava dobrih 46 \% cjelokupne varijabilnosti (Tablica 1).

Razmjerno visoke vrijednosti »Cronbachova $\alpha$ koeficijenta pouzdanosti « (Tablica 1) potvrđuju pouzdanost mjernoga instrumenta za utvrđivanje stupnja razvijenosti zaštite zdravlja i sigurnosti na radu.

O primjerenosti predstavljenog faktorskog modela govore i rezultati konfirmatorne faktorske analize. Na temelju stupnja relevantnosti hi-kvadrat testa u visini 0,144 (Schumacker \& Lomax, 2004.) nije moguće potvrditi statistički relevantne razlike između teorijskih modela $\mathrm{i}$ stvarnih poveznica između proučavanih kategorija. Vrijednost RMSEA pokazatelja 0,0414 niža je od već prihvatljive vrijednosti (Schumacker \& Lomax, 2004.), što potvrđuje prihvatljivost dobivenoga rješenja. 
Tablica 1. Rotirano faktorsko rješenje („oblimin" rotacija) - tzv. „pattern” težina

Table 1. Rotated factor solution (oblimin rotation) - the so-called weighted pattern

\begin{tabular}{|c|c|c|c|}
\hline \multirow[b]{2}{*}{ Aktivnosti/mjere menadžmenta ZZSR-a } & \multicolumn{3}{|c|}{ Perspektiva menadžmenta zaštite na radu } \\
\hline & $\begin{array}{c}\text { Perspektiva } \\
\text { organiziranosti }\end{array}$ & $\begin{array}{c}\text { Perspektiva } \\
\text { dokumentiranosti }\end{array}$ & $\begin{array}{l}\text { Perspektiva } \\
\text { redovitoga } \\
\text { praćenja }\end{array}$ \\
\hline $\begin{array}{l}\text { Poslodavac je izvodio preventivne mjere te izabirao metode rada i } \\
\text { proizvođačke metode koje osiguravaju poboljšanje stanja i višu razinu } \\
\text { zaštite zdravlja i sigurnosti na radu. }\end{array}$ & 0,824 & $-0,065$ & 0,047 \\
\hline $\begin{array}{l}\text { Poslodavac je provodio redovit i temeljit unutarnji nadzor nad } \\
\text { izvođenjem mjera za siguran rad. }\end{array}$ & 0,784 & $-0,106$ & 0,105 \\
\hline $\begin{array}{l}\text { Poslodavac je zaposlenicima odnosno njihovim predstavnicima } \\
\text { omogućio da sudjeluju u raspravi o svim pitanjima koja se tiču } \\
\text { osiguravanja sigurnoga i zdravoga rada. }\end{array}$ & 0,728 & 0,091 & $-0,071$ \\
\hline $\begin{array}{l}\text { Poslodavac je osigurao sigurno radno okruženje i upotrebu sigurne } \\
\text { radne opreme. }\end{array}$ & 0,728 & 0,016 & $-0,038$ \\
\hline $\begin{array}{l}\text { Poslodavac je upoznao radnike s vrstama opasnosti u radnome } \\
\text { okruženju i na radnome mjestu te sa sigurnosnim mjerama potrebnima } \\
\text { za sprečavanje opasnosti i za smanjenje štetnih posljedica. }\end{array}$ & 0,721 & $-0,017$ & 0,073 \\
\hline Poslodavac je radnicima davao primjerene upute i obavijesti. & 0,718 & 0,091 & 0,023 \\
\hline $\begin{array}{l}\text { Poslodavac je izjavu o sigurnosti s ocjenom rizika objavio i posredovao } \\
\text { je radnicima, jednako kao i novozaposlenima i svim drugim nazočnima } \\
\text { na radnome mjestu. }\end{array}$ & 0,713 & 0,019 & $-0,051$ \\
\hline $\begin{array}{l}\text { Poslodavac trajno čuva dokumentaciju koja se odnosi na nezgode na } \\
\text { radu i na kolektivne nezgode. }\end{array}$ & 0,005 & 0,880 & 0,031 \\
\hline $\begin{array}{l}\text { Poslodavac trajno čuva dokumentaciju koja se odnosi na provedeno } \\
\text { osposobljavanje za siguran rad i testove osposobljenosti. }\end{array}$ & 0,009 & 0,846 & 0,026 \\
\hline $\begin{array}{l}\text { Poslodavac je provodio obvezne povremene testove teorijske i praktične } \\
\text { osposobljenosti za siguran rad za radnike koji su radili na radnim } \\
\text { mjestima na kojima iz ocjene rizika proizlazi veća opasnost od nezgoda } \\
\text { i profesionalnih bolesti, kao i za radnike koji su radili na radnim } \\
\text { mjestima na kojima su nezgode na radu i profesionalne bolesti češće. }\end{array}$ & $-0,040$ & $-0,010$ & 0,916 \\
\hline $\begin{array}{l}\text { Poslodavac je povremenim pregledima i testovima radne opreme } \\
\text { provjeravao odgovara li ona propisima o zaštiti zdravlja i sigurnosti na } \\
\text { radu. }\end{array}$ & 0,117 & 0,107 & 0,555 \\
\hline Udio sveukupne objašnjene varijance (\%) & 46,526 & 9,951 & 5,690 \\
\hline Cronbachov $\alpha$ koeficijent & 0,890 & 0,827 & 0,736 \\
\hline
\end{tabular}

\section{RASPRAVA I ZAKLJUČAK}

Svrha je rada predstaviti razvoj i provjeru cjelovitoga mjernog instrumenta za utvrđivanje stupnja razvijenosti ZZSR-a u organizaciji. Mjerni instrument bio je sastavljen i iskušan na temelju teorijskoga i praktičnoga koncepta o ZZSR-u i trebao bi biti učinkovito oruđe pri procjenjivanju razvijenosti ZZSR-a. Konceptualni okvir predstavljale su temeljne funkcije menadžmenta: planiranje, organiziranje, vođenje i kontroliranje zaštite zdravlja i sigurnosti na radu te je polazište imao u Europskoj direktivi o poticanju mjera za poboljšanje ZZSR-a te u slovenskome zakonu o ZZSR-u. 
Od ukupno 55 pokazatelja uključenih u početni faktorski model u konačnome modelu autori su zadržali njih 11. Vrijednost KMO pokazatelja u visini 0,869 , kao i procjene komunaliteta, koje su iznosile između 0,470 i 0,803, potvrđuju primjerenost skupa pokazatelja uključenih u konačnome modelu. Na temelju rotiranih ocjena faktorskih težina moguće je razaznati da je područje izvođenja funkcija menadžmenta ZZSR-a moguće proučavati iz sljedećih triju perspektiva:

1. perspektive organiziranosti funkcija menadžmenta ZZSR-a (7 pokazatelja),

2. perspektive dokumentiranosti postupaka povezanih sa ZZSR-om (2 pokazatelja) i

3. perspektive redovitoga praćenja izvođenja mjera ZZSR-a (2 pokazatelja). S pomoću objašnjenih triju perspektiva moguće je objasniti dobrih $62 \%$ cjelokupne varijabilnosti uzorka, pri čemu je najvažnija perspektiva organiziranosti koja objašnjava dobrih 46 \% cjelokupne varijabilnosti.

Rezultate dobivene spomenutim analizom u nekim je dijelovima moguće, odnosno nužno usporediti s rezultatima sličnih, već provedenih studija, u kojima su istraživači proučavali mjerenje razvijenosti ZZSR-a (iz zakonom propisanih mjera poput Konvencija ILO, Direktiva EU-a, zakonâ, pravilnikâ, odredbi itd., ili iz preporuka po izboru, poput OHSAS 18001, ILO-OSH 2001 itd.). Iz raspoložive literature o mjerenju razvijenosti ZZSR-a razvidno je da se istraživači zauzimaju za to da pokazatelja bude što manje, samo nekoliko ili najviše dvanaest ključnih (Keeble et al., 2003., Qien et al., 2011.), a tu su preporuku autori u ovome istraživanju potpuno slijedili. $U$ istraživanju je utvrđeno da su norveški istraživači Alteren i Hovden (1998.) s pomoću metode zvane Safety Element Method (SEM) došli do prilično sličnih konstatacija te da postoji sljedećih šest glavnih pokazatelja: ciljevi i namjere, menadžment, povratne informacije i učenje, sigurnosna kultura, dokumentacija te indikatori radnih uvjeta koji se djelomično podudaraju i s tvrdnjama autora ovog članka. Djelomično se ovi rezultati podudaraju i s Univerzalnim mjernim instrumentom za procjenu razvijenosti ZZSR-a, razvijenim na Sveučilištu u Michiganu i s kojim su autori ustanovili da ga je moguće proučavati iz sljedećih pet perspektiva: inicijalizacije - rezultata; formalizacije - procesa; implementacije/operacionalizacije - procesa, evaluacije - povratne informacije te poboljšanja/integracije (Redinger \& Levine, 1998.). S rezultatima našega istraživanja pretežno se podudaraju spoznaje koje donose Roy i sur. (2005.) koji su identificirali devet ključnih područja za samoocjenjivanje ZZSR-a: organizacijski sustavi, obvezanost menadžerâ, odgovornost zaposlenih, norme i ponašanje, konstantna poboljšanja, preventivno usmjerene aktivnosti, organizacijska struktura, komuniciranje te motiviranje na radnome mjestu. Nadalje, rezultati ovog istraživanja samo se djelomično podudaraju s mjernim instrumentom Tripod data (Cambon \& Guarnieri, 2008.) kojim su autori utvrdili da ZZSR ovisi o: planovima menadžmenta, održavanju discipline te redu i učinkovitoj komunikaciji. Najveće sadržajno podudaranje utvrdili su autori ovog članka usporedbom istraživanja s istraživanjem Podgorskoga (2015.) koji je mjerni instrument razvijenosti ZZSR-a raščlanio na sljedećih pet ključnih područja: politiku ZZSR-a, organiziranje, komuniciranje, planiranje i implementaciju te provjeru i poboljšanje. Njegovih 20 ključnih pokazatelja (među koje su uključeni i pokazatelji radnih uvjeta), za koje navodi da ih je previše, u potpunosti se slažu s naših 11 pokazatelja.

Oblikovan i provjeren mjerni instrument ima teorijske i praktične implikacije za sigurnosnu znanost o sigurnosti i struku. Sustavnim pregledom te sažetim opisom pregleda rezultata iz dosadašnjih istraživanja $s$ područja mjernoga instrumenta za utvrđivanje stupnja razvijenosti ZZSR-a autori su ponudili cjelovit uvid u proučavane sadržaje. Na temelju mjernoga instrumenta oblikovali su konceptualni model koji se može upotrijebiti, provjeriti i razvijati. Mjerni instrument za utvrđivanje stupnja razvijenosti izvorno je i korisno pomagalo te će biti primjenjiv kako kreatorima politike ZZSR-a u određenoj državi, 
vlasnicima i menadžerima, zaposlenima i njihovim zastupnicima, tako i stručnjacima za ZZSR u poduzeću ili drugoj ustanovi.

U ovome istraživanju autori su otkrili različita ograničenja koja su utjecala na tijek samoga istraživanja i interpretaciju dobivenih informacija. Istraživanje je bilo ograničeno na velika i srednje velika slovenska poduzeća. Određena ograničenja istraživanja proizlaze iz primijenjene metode, tj. ankete: dobiveni su samo podatci na odgovore na koje su osobe koje su odgovarale željele i morale odgovoriti. Za koncept mjernoga instrumenta upotrijebljeni su zahtjevi koji proizlaze iz sadržaja Europske direktive 89/391/EEZ o poticanju mjera za poboljšanje ZZSR-a te iz slovenskoga Zakona o varnosti in zdravju pri delu (Zakona o sigurnosti i zdravlju na radu), ali ne i iz drugih zakona, kao što su Zakon o zdravstvenem varstvu in zdravstvenem zavarovanju (Zakon o zdravstvenoj zaštiti i zdravstvenome osiguranju), Zakon o zavarovalništvu (Zakon o osiguranju) ili Zakon o delovnih razmerjih (Zakon o radnim uvjetima) itd.

$\mathrm{Na}$ temelju provedenoga istraživanja i dobivenih rezultata dane su smjernice za daljnje istraživanje, tj. za širenje istraživanja i na mala poduzeća i mikropoduzeća, što će potencijalnim za istraživače biti poseban izazov. Takav tip istraživanja bilo bi smisleno (uz nekoliko promjena ili prilagodbi) provesti i na svim javnim zavodima, državnim institucijama, odnosno u neprivredi.

\section{Zahvala}

Istraživački program br. P5-0049 sufinancirala je Javna agencija za raziskovalno dejavnost Republike Slovenije (Javna agencija za istraživačku djelatnost Republike Slovenije) iz državnoga proračuna. 


\section{Mjerni instrument za utvrđivanje stupnja razvijenosti zaštite zdravlja i sigurnosti na radu}

\section{A. OSNOVNI PODATCI O POSLOVNOME SUBJEKTU}

1. Ime tvrtke/organizacije. Unesite:

2. Matični broj tvrtke. Unesite deseteroznamenkasti broj:

3. Registracijski broj tvrtke za ZZSR. Unesite deseteroznamenkasti broj:

\section{Poslovna aktivnost:}
1) $\square$ Poljoprivreda i lov, šumarstvo, ribarstvo (A)
11) $\square$ Financijske i osiguravateljske djelatnosti (K)
2) $\square$ Rudarstvo (B)
12) $\square$ Poslovanje nekretninama (L)
3) $\square$ Proizvodnja (C)
13) $\square$ Stručne, znanstvene i tehničke djelatnosti (M)
4) $\square$ Opskrba el. energijom, plinom i parom (D)
14) $\square$ Ostale raznovrsne poslovne djelatnosti (N)
5) $\square$ Opsk. vodom; post. s otp. vod., san. okol. (E)
15) $\square$ Javna uprava i obrana; obv. soc. sigurnost (O)
6) $\square$ Građevinarstvo (F)
16) $\square$ Obrazovanje (P)
7) $\square$ Trgovina; održav. i poprav. mot. vozila (G)
17) $\square$ Zdravstveni i socijalni $\operatorname{rad}(\mathrm{Q})$
8) $\square$ Prijevoz i skladištenje (H)
9) $\square$ Ugostiteljstvo (I)
10) $\square$ Informacijske i komunik. aktivnosti. (J)
18) $\square$ Kulturne, zabavne i rekreacijske akt. (R)
19) $\square$ Ostale djelatnosti (S)

\section{Regija:}
1) $\square$ Pomurska
2) $\square$ Podravska
3) $\square$ Koroška
4) $\square$ Savinjska
5) $\square$ Zasavska
6) $\square$ Spodnjeposavska

7) $\square$ Jugozahodna Slovenija
8) $\square$ Osrednjeslovenska
9) $\square$ Gorenjska
10) $\square$ Notranjsko-kraška
11) $\square$ Goriška
12) $\square$ Obalno-kraška

6. Veličina poslovnoga subjekta:

1) $\square$ Srednja tvrtka/org., s 50 do 250 zaposlenika

2) $\square$ Velika tvrtka/org., s više od 250 zaposlenika

\section{Starost društva/organizacije:}
1) $\square$ Do 10 godina
4) $\square$ Od 31 godine do 40 godina
2) $\square$ Od 11 do 20 godina
5) $\square$ Od 41 godine do 50 godina
3) $\square$ Od 21 godine do 30 godina
6) $\square$ Više od 50 godina 
8. U tvrtki smo usvojili sljedeća načela standarda/modela te djelovali prema njima:
1) ISO $9001 / \mathrm{kvaliteta}$
$\square \mathrm{Da} \square \mathrm{Ne} \square$ Planiramo
Ne razmatramo uvođenje
2) ISO 14001/okoliš
$\square \mathrm{Da} \square \mathrm{Ne} \square$ Planiramo
Ne razmatramo uvođenje
3) OHSAS 18001/sigurnost na radu
$\square \mathrm{Da} \square \mathrm{Ne} \square$ Planiramo
Ne razmatramo uvođenje
4) ISO $22000 / \mathrm{HACCP}$
$\square \mathrm{Da} \square \mathrm{Ne} \square$ Planiramo
Ne razmatramo uvođenje
5) ISO 26000/društvena odgovornost
$\square \mathrm{Da} \square \mathrm{Ne} \square$ Planiramo
$\mathrm{Da}$
Planiramo
$\square$ Ne razmatramo uvođenje
6) Model izvrsnosti EFQM

\section{B. MENADŽMENT SIGURNOSTI NA RADU}

\section{Organizacija:}

1) $\square$ Poslodavac je za obavljanje stručnih poslova zaštite sigurnosti na radu odredio jednoga ili više stručnjaka za sigurnost na radu - organizirao je službu za sigurnost na radu.

2) $\square$ Poslodavac je obavljanje zadataka organiziranja i osiguravanja zaštite sigurnosti na radu povjerio vanjskoj stručnoj službi s radnom dozvolom.

3) $\square$ Poslodavac je osigurao da zdravstvene mjere koje su u vezi sa sigurnošću i zdravljem na radu provodi specijalist medicine rada.

4) $\square$ Poslodavac je osnovao Odbor za sigurnost i zdravlje na radu, koji se sastoji od predstavnikâ uprave, radnika, te stručnjaka za zaštitu zdravlja i sigurnosti na radu.

10. U slučaju da stručnjak za sigurnost na radu ili Služba za sigurnost rada djeluju u sklopu tvrtke, u organizacijskoj su strukturi tvrtke smješteni:

1) $\square$ na prvoj razini upravljanja (izravno ispod uprave)

2) $\square$ na drugoj razini upravljanja (izravno ispod upravitelja)

3) $\square$ na trećoj razini upravljanja (izravno ispod vodstva sektora)

4) $\square$ na četvrtome ili nižemu stupnju upravljanja (izravno ispod vodstva odjela)

\section{Stručnjak ili služba za sigurnost na radu, odnosno vanjski pružatelj usluga sigurnosti na} radu komunicira izravno s vodstvom poduzeća:
1) $\square$ jednom tjedno
2) $\square$ mjesečno
3) $\square$ nekoliko puta godišnje
4) $\square$ jednom godišnje
5) $\square$ nikada

\section{Postojeći sustav upravljanja sigurnošću na radu u tvrtki na snazi je:}

1) $\square$ manje od jedne godine

2) $\square$ od jedne godine do pet godina

3) $\square$ više od pet godina 


\section{PLANIRANJE (Odgovorite koliko se slažete s navedenim tvrdnjama (0 - 100 \%)):}

\begin{tabular}{|c|c|c|c|c|c|c|c|c|c|c|c|c|}
\hline & $\| \quad 0 \%$ & $\begin{array}{l}10 \\
\%\end{array}$ & $\begin{array}{l}20 \\
\%\end{array}$ & $\begin{array}{l}30 \\
\%\end{array}$ & $\begin{array}{l}40 \\
\%\end{array}$ & $\begin{array}{l}50 \\
\%\end{array}$ & $\begin{array}{l}60 \\
\%\end{array}$ & $\begin{array}{l}70 \\
\%\end{array}$ & $\begin{array}{l}80 \\
\%\end{array}$ & $\begin{array}{l}90 \\
\%\end{array}$ & $\begin{array}{c}100 \\
\%\end{array}$ & $\begin{array}{c}\text { Ne } \\
\text { znam } \\
\text { odgovor }\end{array}$ \\
\hline \begin{tabular}{|l||} 
Poslodavac je razvio sveobuhvatnu sigurnosnu \\
politiku koja uključuje tehnologiju, \\
organizaciju rada, radne uvjete, međuljudske \\
odnose te čimbenike radnoga okruženja.
\end{tabular} & C & $\mathrm{C}$ & C & C & $\mathrm{C}$ & $\mathrm{C}$ & C & $\mathrm{C}$ & C & $\mathrm{C}$ & $\mathrm{C}$ & $\mathrm{C}$ \\
\hline \begin{tabular}{|l||} 
Nakon provedbe procjene rizika za sigurnost i \\
zdravlje na radu, poslodavac je izradio i \\
usvojio pisanu procjenu rizika s izjavom, koja \\
sadržava plan za provedbu propisanih zahtjeva.
\end{tabular} & $C$ & $\mathrm{C}$ & C & C & $\mathrm{C}$ & $\mathrm{C}$ & C & $\mathrm{C}$ & C & $\mathrm{C}$ & C & $\mathrm{C}$ \\
\hline $\begin{array}{l}\text { Pri planiranju rada poslodavac je uzimao u } \\
\text { obzir mentalne i tjelesne sposobnosti radnikâ } \\
\text { te smanjio rizik opterećenja koja utječu na } \\
\text { sigurnost i zdravlje radnikâ. }\end{array}$ & C & $\mathrm{C}$ & $\mathrm{C}$ & C & $\mathrm{C}$ & $\mathrm{C}$ & C & $\mathrm{C}$ & C & C & $C$ & C \\
\hline $\begin{array}{l}\text { Poslodavac je planirao promicati zdravlje na } \\
\text { radnome mjestu te je za to osigurao potrebna } \\
\text { sredstva, kao i način praćenja provedbe. }\end{array}$ & C & $\mathrm{C}$ & $\mathrm{C}$ & C & C & C & C & C & $\mathrm{C}$ & $\mathrm{C}$ & C & C \\
\hline $\mid \begin{array}{l}\text { Poslodavac je poduzeo mjere za sprečavanje i } \\
\text { uklanjanje nasilja, zlostavljanja, uznemiravanja } \\
\text { i drugih oblika psihosocijalnog rizika na } \\
\text { radnim mjestima, kao i za rješavanje takvih } \\
\text { slučajeva. }\end{array}$ & 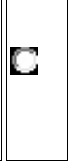 & 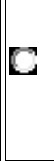 & $\mathrm{C}$ & $\mathrm{C}$ & $\mathrm{C}$ & $\mathrm{E}$ & $\mathrm{C}$ & $\mathrm{C}$ & $\mathrm{C}$ & $\mathrm{C}$ & $\mathrm{C}$ & C \\
\hline
\end{tabular}

14. ORGANIZIRANJE (Odgovorite koliko se slažete s navedenim tvrdnjama (0 - $100 \%)$ ):

\begin{tabular}{|c|c|c|c|c|c|c|c|c|c|c|c|c|}
\hline & ( $0 \%$ & $\begin{array}{l}10 \\
\%\end{array}$ & $\begin{array}{l}20 \\
\%\end{array}$ & $\begin{array}{l}30 \\
\%\end{array}$ & $\begin{array}{l}40 \\
\%\end{array}$ & $\begin{array}{l}50 \\
\%\end{array}$ & $\begin{array}{l}60 \\
\%\end{array}$ & $\begin{array}{l}70 \\
\%\end{array}$ & $\begin{array}{l}80 \\
\%\end{array}$ & $\begin{array}{l}90 \\
\%\end{array}$ & $\begin{array}{c}100 \\
\%\end{array}$ & $\begin{array}{l}\text { Ne znam } \\
\text { odgovor }\end{array}$ \\
\hline $\begin{array}{l}\text { Poslodavac je osigurao sigurnost i zdravlje } \\
\text { radnika na poslu. S tim je ciljem provodio } \\
\text { mjere koje su neophodne da bi se osigurala } \\
\text { sigurnost i zdravlje radnikâ te drugih osoba } \\
\text { prisutnih u radnome procesu. }\end{array}$ & C & C & $C$ & C & C & C & $\mathrm{C}$ & $\mathrm{C}$ & C & C & C & C \\
\hline $\begin{array}{l}\text { Poslodavac je u pisanom obliku procjenjivao } \\
\text { rizike kojima su radnici izloženi ili će } \\
\text { vjerojatno biti izloženi na poslu. }\end{array}$ & C & $\mathrm{C}$ & C & C & C & C & $\mathrm{C}$ & $\mathrm{C}$ & $\mathrm{C}$ & C & C & C \\
\hline $\begin{array}{l}\text { Poslodavac i zaposlenici ili njihovi } \\
\text { predstavnici međusobno su se obavještavali i } \\
\text { konzultirali o pitanjima sigurnosti i zdravlja } \\
\text { na radu, te su s time u vezi zajednički } \\
\text { donosili odluke. }\end{array}$ & C & $\mathrm{C}$ & C & $\mathrm{C}$ & C & C & $\mathrm{C}$ & $\mathrm{C}$ & $\mathrm{C}$ & $\mathrm{C}$ & $\mathrm{C}$ & C \\
\hline $\begin{array}{l}\text { Poslodavac je izjavu o sigurnosti s ocjenom } \\
\text { rizika objavio i posredovao ju radnicima, } \\
\text { jednako kao i novozaposlenima i svim } \\
\text { drugim nazočnima na radnome mjestu. } \\
\end{array}$ & C & $C$ & C & $\mathrm{C}$ & C & C & C & $\mathrm{C}$ & $\mathrm{C}$ & $\mathrm{C}$ & C & C \\
\hline $\begin{array}{l}\text { Poslodavac je informirao radnike o uvođenju } \\
\text { novih tehnologija i sredstava rada te rizicima } \\
\text { od nezgoda, profesionalnih bolesti i bolesti } \\
\text { povezanih s radom te je dao upute za siguran } \\
\text { rad. }\end{array}$ & C & $\mathrm{C}$ & $\mathrm{C}$ & $\mathrm{C}$ & C & $\mathrm{C}$ & $\mathrm{C}$ & C & $\mathrm{C}$ & $\mathrm{C}$ & C & $\mathrm{C}$ \\
\hline
\end{tabular}




\begin{tabular}{|c|c|c|c|c|c|c|c|c|c|c|c|c|}
\hline & 0 \% & $\begin{array}{l}10 \\
\%\end{array}$ & $\begin{array}{l}20 \\
\%\end{array}$ & $\begin{array}{l}30 \\
\%\end{array}$ & $\begin{array}{l}40 \\
\%\end{array}$ & $\begin{array}{l}\mathbf{5 0} \\
\%\end{array}$ & $\begin{array}{l}60 \\
\%\end{array}$ & $\begin{array}{l}70 \\
\%\end{array}$ & $\begin{array}{l}80 \\
\%\end{array}$ & $\begin{array}{l}90 \\
\%\end{array}$ & $\begin{array}{c}100 \\
\%\end{array}$ & \begin{tabular}{|l|} 
Ne znam \\
odgovor
\end{tabular} \\
\hline $\begin{array}{l}\text { Poslodavac je teorijski osposobio radnike za } \\
\text { siguran i zdrav rad. }\end{array}$ & C & $\mathrm{C}$ & $\mathrm{C}$ & $\mathrm{C}$ & $\mathrm{C}$ & $\mathrm{C}$ & $\mathrm{C}$ & $\mathrm{C}$ & $\mathrm{C}$ & $\mathrm{C}$ & $\mathrm{C}$ & C \\
\hline $\begin{array}{l}\text { Poslodavac je praktično obučio radnike za } \\
\text { siguran i zdrav rad na samome radnom } \\
\text { mjestu. }\end{array}$ & C & $\mathbf{C}$ & $\mathrm{C}$ & C & $\mathrm{C}$ & C & C & $\mathrm{C}$ & $\mathrm{C}$ & $\mathrm{C}$ & C & C \\
\hline $\begin{array}{l}\text { Poslodavac je radnicima osigurao osobnu } \\
\text { zaštitnu opremu i njihovu upotrebu. }\end{array}$ & $\mathrm{C}$ & $\mathbf{C}$ & $\mathrm{C}$ & $\mathrm{C}$ & $\mathrm{C}$ & $\mathrm{C}$ & $\mathrm{C}$ & $\mathrm{C}$ & $\mathrm{C}$ & $\mathrm{C}$ & $\mathrm{C}$ & $\mathrm{C}$ \\
\hline $\begin{array}{l}\text { Poslodavac je osigurao sigurno radno } \\
\text { okruženje i upotrebu sigurne radne opreme }\end{array}$ & C & $\mathbf{C}$ & $\mathbf{C}$ & $\mathbf{C}$ & $\mathbf{C}$ & $\mathbf{C}$ & $\mathbf{C}$ & $\mathrm{C}$ & $\mathrm{C}$ & $\mathrm{C}$ & $\mathrm{C}$ & $\mathrm{C}$ \\
\hline $\begin{array}{l}\text { Poslodavac je poduzeo potrebne mjere da se } \\
\text { osigura pružanje prve pomoći djelatnicima i } \\
\text { drugim prisutnim osobama te da se surađuje } \\
\text { sa službom hitne medicinske pomoći. }\end{array}$ & $\mathrm{C}$ & $\mathbf{C}$ & $\mathrm{C}$ & $\mathrm{C}$ & $\mathrm{C}$ & $\mathrm{C}$ & $\mathrm{C}$ & $\mathrm{C}$ & $\mathrm{C}$ & $\mathrm{C}$ & C & $\mathrm{C}$ \\
\hline $\begin{array}{l}\begin{array}{l}\text { Poslodavac je poduzeo potrebne mjere da se } \\
\text { osigura zaštitu od požara i evakuacija. }\end{array} \\
\end{array}$ & $\mathbf{C}$ & $\mathbf{C}$ & C & $\mathrm{C}$ & C & $\mathrm{C}$ & $\mathrm{C}$ & $\mathrm{C}$ & $\mathrm{C}$ & $\mathrm{C}$ & $\mathrm{C}$ & C \\
\hline $\begin{array}{l}\begin{array}{l}\text { Poslodavac se na mjestima gdje postoji veći } \\
\text { rizik od nasilja trećih osoba pobrinuo da se } \\
\text { radno mjesto i oprema urede tako da se } \\
\text { smanji opasnost od nasilja i omogući pristup } \\
\text { pomoći. }\end{array} \\
\end{array}$ & C & $\mathbf{C}$ & C & C & C & C & C & $E$ & $C$ & $\mathrm{C}$ & C & C \\
\hline $\begin{array}{l}\text { U skladu s propisima o sigurnosti i zdravlju } \\
\text { na radu, za objekte kojima se koristi } \\
\text { Poslodavac ima svu dokumentaciju. }\end{array}$ & C & $\mathbf{C}$ & $\mathrm{C}$ & $\mathrm{C}$ & $\mathrm{C}$ & $C$ & $C$ & $\mathrm{C}$ & $\mathrm{C}$ & $\mathrm{C}$ & C & $\mathbf{C}$ \\
\hline \begin{tabular}{|l|} 
Poslodavac je radnu opremu i druga sredstva \\
za rad dopustio upotrebljavati samo onda \\
kada je dobio dokumentaciju koja osigurava \\
poštivanje bitnih zdravstvenih i sigurnosnih \\
zahtjeva.
\end{tabular} & $\mathrm{C}$ & $\mathbf{C}$ & $\mathrm{C}$ & $\mathrm{C}$ & $\mathrm{C}$ & $\mathrm{C}$ & $\mathrm{C}$ & $\mathbf{C}$ & $\mathrm{C}$ & $\mathrm{C}$ & C & $\mathrm{C}$ \\
\hline \begin{tabular}{|l||} 
Poslodavac je korištenje opasnih kemijskih \\
tvari radnicima dopustio samo ako uz njih \\
dolazi sigurnosni list u kojemu su proizvođač \\
ili dobavljač naveli sve sigurnosno-tehničke \\
podatke.
\end{tabular} & C & $\mathbf{C}$ & $\mathrm{C}$ & $\mathrm{C}$ & $\mathrm{C}$ & $\mathbf{C}$ & $\mathrm{C}$ & $\mathrm{C}$ & $\mathrm{C}$ & $\mathrm{C}$ & C & $\mathrm{C}$ \\
\hline $\begin{array}{l}\text { Poslodavac je osigurao da upute za siguran } \\
\text { rad i sigurnosni listovi budu na jeziku koji } \\
\text { radnik razumije. }\end{array}$ & C & $\mathrm{C}$ & $C$ & $\mathrm{C}$ & $\mathrm{C}$ & $C$ & $C$ & $\mathrm{C}$ & $\mathrm{C}$ & $C$ & C & $\mathrm{C}$ \\
\hline $\begin{array}{l}\begin{array}{l}\text { Stručnjak za sigurnost na radu i specijalist } \\
\text { medicine rada surađivali su pri obavljanju } \\
\text { poslova zaštite na radu. }\end{array} \\
\end{array}$ & C & $\mathbf{C}$ & C & $\mathrm{C}$ & $\mathrm{C}$ & $\mathrm{C}$ & $\mathrm{C}$ & $\mathrm{C}$ & $\mathrm{C}$ & C & $\mathrm{C}$ & $\mathrm{C}$ \\
\hline $\begin{array}{l}\begin{array}{l}\text { Poslodavac je osigurao medicinske preglede } \\
\text { radnicima za koje se procjenjuje rizik u vezi } \\
\text { sa sigurnošću i zdravljem na radu. }\end{array} \\
\end{array}$ & C & $\mathbf{C}$ & C & C & $\mathrm{C}$ & $\mathrm{C}$ & $\mathrm{C}$ & $\mathbf{E}$ & $\mathrm{C}$ & $\mathrm{C}$ & C & $\mathrm{C}$ \\
\hline $\begin{array}{l}\begin{array}{l}\text { Poslodavac je obavijestio radnike o } \\
\text { sigurnome i zdravome radu te objavio pisane } \\
\text { obavijesti i upute. }\end{array} \\
\end{array}$ & C & $\mathbf{C}$ & $\mathbf{C}$ & $\mathbf{C}$ & $\mathrm{C}$ & $\mathrm{C}$ & $C$ & $\mathrm{C}$ & $\mathbf{C}$ & $\mathrm{C}$ & C & $\mathbf{C}$ \\
\hline \begin{tabular}{|l|} 
Poslodavac je upoznao radnike s vrstama \\
opasnosti u radnome okruženju i na radnome \\
mjestu te sa sigurnosnim mjerama potrebnima \\
za sprečavanje opasnosti i za smanjenje \\
štetnih posljedica.
\end{tabular} & C & $\mathbf{C}$ & $\mathrm{C}$ & $\mathrm{C}$ & $\mathrm{C}$ & $\mathrm{C}$ & $\mathrm{C}$ & $\mathrm{C}$ & $\mathrm{C}$ & $\mathrm{C}$ & $\mathrm{C}$ & $\mathrm{C}$ \\
\hline
\end{tabular}




\begin{tabular}{|c|c|c|c|c|c|c|c|c|c|c|c|c|}
\hline & $0 \%$ & $\begin{array}{l}10 \\
\%\end{array}$ & $\begin{array}{l}20 \\
\%\end{array}$ & $\begin{array}{l}30 \\
\%\end{array}$ & $\begin{array}{l}40 \\
\%\end{array}$ & $\begin{array}{l}50 \\
\%\end{array}$ & $\begin{array}{l}60 \\
\%\end{array}$ & $\begin{array}{l}70 \\
\%\end{array}$ & $\begin{array}{l}80 \\
\%\end{array}$ & $\begin{array}{l}90 \\
\%\end{array}$ & \begin{tabular}{|c||}
100 \\
$\%$
\end{tabular} & \begin{tabular}{|l|}
$\begin{array}{l}\text { Ne znam } \\
\text { odgovor }\end{array}$ \\
\end{tabular} \\
\hline $\begin{array}{l}\text { Poslodavac je osposobio radnika da sigurno } \\
\text { obavlja posao prilikom zasnivanja radnoga } \\
\text { odnosa, prije angažmana na drugome poslu, } \\
\text { prije uvođenja nove tehnologije i novih } \\
\text { radnih sredstava. }\end{array}$ & C & $\mathbf{C}$ & $\mathrm{C}$ & $\mathrm{C}$ & $\mathrm{C}$ & $\mathrm{C}$ & $\mathrm{C}$ & $\mathrm{C}$ & $\mathrm{C}$ & $\mathrm{C}$ & C & $\mathbf{C}$ \\
\hline $\begin{array}{l}\begin{array}{l}\text { Poslodavac je prije početka radnoga procesa u } \\
\text { kojemu postoji veći rizik od nezgoda i } \\
\text { profesionalnih bolesti obavijestio inspektorat } \\
\text { rada }\end{array} \\
\end{array}$ & C & $\mathbf{C}$ & C & C & C & C & C & $C$ & $C$ & $\mathrm{C}$ & C & C \\
\hline \begin{tabular}{|l||} 
Poslodavac je prijavio svaku nesreću na radu \\
sa smrtnim posljedicama ili nesreću na radu \\
zbog koje je radnik nesposoban za rad više od \\
tri radna dana, kolektivne nezgode, opasne \\
pojave i utvrđene profesionalne bolesti.
\end{tabular} & C & $\mathrm{C}$ & $\mathrm{C}$ & $\mathrm{C}$ & $\mathrm{C}$ & $\mathrm{C}$ & $\mathrm{C}$ & $\mathrm{C}$ & $\mathrm{C}$ & $\mathrm{C}$ & C & $\mathbf{C}$ \\
\hline \begin{tabular}{|l|} 
Poslodavac je zaposlenicima odnosno \\
njihovim predstavnicima omogućio da \\
sudjeluju u raspravi o svim pitanjima koja se \\
tiču osiguravanja sigurnoga i zdravoga rada.
\end{tabular} & $\mathrm{C}$ & $\mathbf{C}$ & $\mathrm{C}$ & $\mathrm{C}$ & $\mathrm{C}$ & $\mathrm{C}$ & $\mathrm{C}$ & $\mathrm{C}$ & $\mathrm{C}$ & $\mathrm{C}$ & $\mathrm{C}$ & $\mathrm{C}$ \\
\hline $\begin{array}{l}\text { Poslodavac se savjetovao s radnicima ili } \\
\text { njihovim predstavnicima o procjeni rizika, } \\
\text { kao i o svim aktivnostima koje mogu utjecati } \\
\text { na sigurnost i zdravlje na radu. }\end{array}$ & $C$ & $\mathrm{C}$ & $\mathrm{C}$ & $\mathrm{C}$ & $\mathrm{C}$ & $C$ & $C$ & $\mathrm{C}$ & $\mathrm{C}$ & $\mathrm{C}$ & $\mathrm{C}$ & $\mathrm{C}$ \\
\hline $\begin{array}{l}\begin{array}{l}\text { Poslodavac je predstavnicima radnika i } \\
\text { sindikatima koji su organizirani kod njega } \\
\text { proslijedio sigurnosnu izjavu s procjenom } \\
\text { rizika i dokumentacijom o nezgodama na } \\
\text { radu. }\end{array} \\
\end{array}$ & $\mathrm{C}$ & $\mathbf{C}$ & $C$ & $\mathrm{C}$ & $\mathrm{C}$ & $\mathrm{C}$ & $C$ & $\mathrm{C}$ & $C$ & $C$ & $\mathrm{C}$ & $\mathrm{C}$ \\
\hline $\begin{array}{l}\text { Poslodavac je Vijeće radnika ili zastupnika } \\
\text { radnika za radnu sigurnost i zdravlje te } \\
\text { sindikate poslodavaca obavijestio o nalazima, } \\
\text { prijedlozima ili postupcima nadzornih tijela. }\end{array}$ & $\mathrm{C}$ & $\mathrm{C}$ & $C$ & $\mathrm{C}$ & $\mathrm{C}$ & $\mathrm{C}$ & $C$ & $\mathrm{C}$ & $\mathrm{C}$ & $\mathrm{C}$ & C & $\mathbf{C}$ \\
\hline
\end{tabular}

15. VOĐENJE (Odgovorite koliko se slažete s navedenim tvrdnjama (0 - 100 \%)):

\begin{tabular}{|c|c|c|c|c|c|c|c|c|c|c|c|c|}
\hline & $0 \%$ & $\begin{array}{l}10 \\
\%\end{array}$ & $\begin{array}{l}20 \\
\%\end{array}$ & $\begin{array}{l}30 \\
\%\end{array}$ & $\begin{array}{l}40 \\
\%\end{array}$ & $\begin{array}{l}50 \\
\%\end{array}$ & $\begin{array}{l}60 \\
\%\end{array}$ & $\begin{array}{l}70 \\
\%\end{array}$ & $\begin{array}{l}80 \\
\%\end{array}$ & $\begin{array}{l}90 \\
\%\end{array}$ & $\begin{array}{l}100 \\
\%\end{array}$ & $\begin{array}{l}\text { Ne znam } \\
\text { odgovor }\end{array}$ \\
\hline \begin{tabular}{|l}
$\begin{array}{l}\text { Poslodavac je osigurao sigurnost i zdravlje } \\
\text { trudnih radnica, mladih i starijih radnika te } \\
\text { radnika sa smanjenom radnom sposobnošću. }\end{array}$ \\
\end{tabular} & C & $\mathrm{C}$ & C & C & $\mathrm{C}$ & $\mathrm{C}$ & $\mathrm{C}$ & $\mathrm{C}$ & $\mathrm{C}$ & $\mathrm{C}$ & $\mathrm{C}$ & C \\
\hline \begin{tabular}{|l} 
Poslodavac je izvodio preventivne mjere te \\
izabirao metode rada i proizvođačke metode \\
koje osiguravaju poboljšanje stanja i višu \\
razinu zaštite zdravlja i sigurnosti na radu.
\end{tabular} & C & $\mathrm{C}$ & $\mathrm{C}$ & $\mathrm{C}$ & $\mathrm{C}$ & $\mathrm{C}$ & $\mathrm{C}$ & $\mathrm{C}$ & C & $\mathrm{C}$ & C & $\mathrm{C}$ \\
\hline $\begin{array}{l}\text { Poslodavac je planirao i provodio promicanje } \\
\text { zdravlja na radnome mjestu. }\end{array}$ & $\mathrm{C}$ & C & C & $\mathrm{C}$ & $\mathrm{C}$ & $\mathrm{C}$ & C & $\mathrm{C}$ & $\mathrm{C}$ & $\mathrm{C}$ & C & $\mathbf{C}$ \\
\hline
\end{tabular}




\begin{tabular}{|c|c|c|c|c|c|c|c|c|c|c|c|c|}
\hline & $0 \%$ & $\begin{array}{l}10 \\
\%\end{array}$ & $\begin{array}{l}20 \\
\%\end{array}$ & $\begin{array}{l}30 \\
\%\end{array}$ & $\begin{array}{l}40 \\
\%\end{array}$ & $\begin{array}{l}50 \\
\%\end{array}$ & $\begin{array}{l}60 \\
\%\end{array}$ & $\begin{array}{l}70 \\
\% \\
\end{array}$ & $\begin{array}{l}80 \\
\%\end{array}$ & $\begin{array}{l}90 \\
\% \\
\end{array}$ & $\begin{array}{l}100 \\
\%\end{array}$ & $\begin{array}{l}\begin{array}{l}\text { Ne znam } \\
\text { odgovor }\end{array} \\
\end{array}$ \\
\hline $\begin{array}{l}\text { Poslodavac je tijekom planiranja radnoga } \\
\text { okoruženja, radnih prostorija, radnih i } \\
\text { tehnoloških postupaka, upotrebe radne i } \\
\text { osobne zaštitne opreme i upotrebe opasnih } \\
\text { kemijskih tvari osigurao da su u obzir uzeti } \\
\text { svi učinci na siguran i zdrav rad radnika te da } \\
\text { su okruženje, postupci, prostori, oprema i } \\
\text { tvari prikladni i u skladu s planiranom } \\
\text { upotrebom. }\end{array}$ & $\mathbf{C}$ & C & $\mathbf{C}$ & $\mathrm{C}$ & $\mathrm{C}$ & $\mathrm{C}$ & $\mathrm{C}$ & $\mathbf{C}$ & C & $\mathrm{C}$ & $\mathbf{C}$ & $\mathrm{C}$ \\
\hline $\begin{array}{l}\begin{array}{l}\text { Poslodavac je radnicima davao primjerene } \\
\text { upute i obavijesti. }\end{array} \\
\end{array}$ & $\mathbf{C}$ & C & $\mathrm{C}$ & $\mathrm{C}$ & $\mathrm{C}$ & $\mathrm{C}$ & $\mathrm{C}$ & $\mathrm{C}$ & C & C & $\mathbf{C}$ & $\mathrm{C}$ \\
\hline $\begin{array}{l}\text { Poslodavac kod kojega na temelju ugovora } \\
\text { poslove obavljaju radnici drugoga poslodavca } \\
\text { osigurao je da radnici dobiju sve informacije } \\
\text { o rizicima za sigurnost i zdravlje na radu, } \\
\text { uključujući i sigurnosnu izjavu, kao i podatke } \\
\text { o radnicima koji su imenovani za pružanje } \\
\text { prve pomoći. }\end{array}$ & D & $\mathrm{C}$ & $\mathrm{C}$ & $\mathrm{C}$ & C & $\mathrm{C}$ & C & $\mathrm{C}$ & $\mathrm{C}$ & C & $\mathbb{C}$ & C \\
\hline $\begin{array}{l}\text { Odbor za sigurnost na radu ima važnu ulogu } \\
\text { u osiguravanju sigurnosti i zdravlja na radu. }\end{array}$ & $\mathbf{C}$ & C & $\mathrm{C}$ & $\mathbf{C}$ & $\mathbf{C}$ & $\mathbf{C}$ & $\mathbf{C}$ & $\mathrm{C}$ & $\mathbf{E}$ & $\mathrm{C}$ & $\mathbf{C}$ & $\mathrm{C}$ \\
\hline
\end{tabular}

16. NADZOR (Odgovorite koliko se slažete s navedenim tvrdnjama $(0-100 \%)$ ):

\begin{tabular}{|c|c|c|c|c|c|c|c|c|c|c|c|c|}
\hline & $0 \%$ & $\begin{array}{l}10 \\
\%\end{array}$ & $\begin{array}{l}20 \\
\%\end{array}$ & $\begin{array}{l}30 \\
\% \\
\end{array}$ & $\begin{array}{l}40 \\
\% \\
\end{array}$ & $\begin{array}{l}50 \\
\% \\
\end{array}$ & $\begin{array}{l}60 \\
\% \\
\end{array}$ & $\begin{array}{l}70 \\
\%\end{array}$ & $\begin{array}{l}80 \\
\%\end{array}$ & $\begin{array}{l}90 \\
\% \\
\end{array}$ & $\begin{array}{l}100 \\
\%\end{array}$ & $\begin{array}{l}\text { Ne znam } \\
\text { odgovor }\end{array}$ \\
\hline $\begin{array}{l}\text { Poslodavac je provodio redovit i temeljit } \\
\text { unutarnji nadzor nad izvođenjem mjera za } \\
\text { siguran rad. }\end{array}$ & C & $\mathrm{C}$ & $\mathrm{C}$ & C & C & $\mathrm{C}$ & $E$ & $\mathrm{C}$ & $\mathrm{C}$ & $\mathrm{C}$ & $\mathrm{C}$ & $\mathrm{C}$ \\
\hline $\begin{array}{l}\text { Poslodavac je periodičniim istraživanjima } \\
\text { štetnosti radnoga okruženja provjeravao } \\
\text { adekvatnost radnih uvjeta. }\end{array}$ & C & C & $\mathrm{C}$ & $\mathrm{C}$ & $\mathrm{C}$ & $\mathrm{C}$ & $\mathrm{C}$ & $\mathrm{C}$ & C & $\mathrm{C}$ & $\mathrm{C}$ & C \\
\hline $\begin{array}{l}\text { Poslodavac je povremenim pregledima i } \\
\text { testovima radne opreme provjeravao } \\
\text { odgovara li ona propisima o zaštiti zdravlja i } \\
\text { sigurnosti na radu. }\end{array}$ & C & $\mathrm{C}$ & $\mathrm{C}$ & $\mathrm{C}$ & $\mathrm{C}$ & $\mathrm{C}$ & $\mathrm{C}$ & $\mathrm{C}$ & $\mathrm{C}$ & $\mathrm{C}$ & C & C \\
\hline $\begin{array}{l}\text { Poslodavac je procjenu rizika korigirao i } \\
\text { ažurirao svaki put kad su postojeće } \\
\text { preventivne zaštitne mjere bile } \\
\text { neodgovarajuće ili više nisu bile relevantne, } \\
\text { kada su se podatci na kojima se procjena } \\
\text { temelji promijenili ili kad su postojale } \\
\text { mogućnosti i načini za dopunu ili dovršenje } \\
\text { procjene. }\end{array}$ & 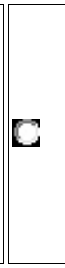 & C & $\mathrm{C}$ & $\mathrm{C}$ & C & $\mathrm{C}$ & $\mathrm{C}$ & $\mathrm{C}$ & $\mathrm{C}$ & $\mathrm{C}$ & C & C \\
\hline \begin{tabular}{|l} 
Poslodavac je provodio obvezne povremene \\
testove teorijske i praktične osposobljenosti \\
za siguran rad za radnike koji su radili na \\
radnim mjestima na kojima iz ocjene rizika \\
proizlazi veća opasnost od nezgoda i \\
profesionalnih bolesti, kao i za radnike koji \\
su radili na radnim mjestima na kojima su \\
nezgode na radu i profesionalne bolesti češće.
\end{tabular} & $\mathrm{C}$ & C & C & $\mathrm{C}$ & C & $\mathrm{C}$ & $\mathrm{C}$ & $C$ & $C$ & $\mathrm{C}$ & $\mathrm{E}$ & 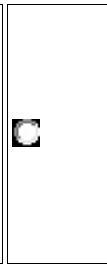 \\
\hline $\begin{array}{l}\text { Sposobnost za siguran rad poslodavac je } \\
\text { provjeravao na radnome mjestu. }\end{array}$ & C & $\mathrm{C}$ & $\mathrm{C}$ & $\mathrm{C}$ & $\mathrm{C}$ & C & C & $C$ & $C$ & C & $\mathrm{C}$ & $\mathrm{C}$ \\
\hline
\end{tabular}




\begin{tabular}{|c|c|c|c|c|c|c|c|c|c|c|c|c|}
\hline & $0 \%$ & $\begin{array}{l}10 \\
\%\end{array}$ & $\begin{array}{l}20 \\
\%\end{array}$ & $\begin{array}{l}30 \\
\%\end{array}$ & $\begin{array}{l}40 \\
\% \\
\end{array}$ & $\begin{array}{l}50 \\
\% \\
\end{array}$ & $\begin{array}{l}60 \\
\% \\
\end{array}$ & $\begin{array}{l}70 \\
\% \\
\end{array}$ & $\begin{array}{l}80 \\
\% \\
\end{array}$ & $\begin{array}{l}90 \\
\% \\
\end{array}$ & $\begin{array}{l}100 \\
\%\end{array}$ & $\begin{array}{l}\text { Ne znam } \\
\text { odgovor }\end{array}$ \\
\hline $\begin{array}{l}\text { Poslodavac je utvrdio jesu li radnici pod } \\
\text { utjecajem lijekova koji mogu utjecati na } \\
\text { psihofizičke sposobnosti. }\end{array}$ & $\mathrm{C}$ & C & $\mathrm{C}$ & $\mathrm{C}$ & $\mathrm{C}$ & $\mathrm{C}$ & $\mathrm{C}$ & $\mathrm{C}$ & $\mathrm{C}$ & $\mathrm{C}$ & $\mathrm{C}$ & C \\
\hline $\begin{array}{l}\text { Poslodavac stalno vodi dokumentaciju koja se } \\
\text { odnosi na periodična istraživanja štetnosti u } \\
\text { radnome okruženju. }\end{array}$ & $\mathrm{C}$ & $\mathrm{C}$ & $\mathrm{C}$ & $\mathrm{C}$ & $\mathrm{C}$ & $\mathrm{C}$ & $\mathrm{C}$ & $\mathrm{C}$ & $\mathrm{C}$ & $\mathrm{C}$ & $\mathrm{C}$ & C \\
\hline $\begin{array}{l}\begin{array}{l}\text { Poslodavac stalno vodi dokumentaciju koja se } \\
\text { odnosi na periodične inspekcije i ispitivanja } \\
\text { radne opreme. }\end{array} \\
\end{array}$ & $\mathbf{C}$ & C & C & $\mathrm{C}$ & $\mathrm{C}$ & $\mathrm{C}$ & $\mathrm{C}$ & $\mathrm{C}$ & $\mathrm{C}$ & $\mathrm{C}$ & $\mathrm{C}$ & $\mathbb{C}$ \\
\hline $\begin{array}{l}\begin{array}{l}\text { Poslodavac stalno vodi evidenciju koja se } \\
\text { odnosi na inspekcije i testove osobne zaštitne } \\
\text { opreme. }\end{array} \\
\end{array}$ & C & C & $\mathrm{C}$ & $\mathrm{C}$ & $\mathrm{C}$ & $\mathrm{C}$ & $\mathrm{C}$ & $\mathrm{C}$ & $\mathrm{C}$ & $\mathrm{C}$ & $\mathrm{C}$ & C \\
\hline $\begin{array}{l}\text { Poslodavac trajno čuva dokumentaciju koja } \\
\text { se odnosi na provedeno osposobljavanje za } \\
\text { siguran rad i testove osposobljenosti. }\end{array}$ & $\mathrm{C}$ & C & $\mathbf{C}$ & $\mathrm{C}$ & $\mathrm{C}$ & $\mathbf{C}$ & $\mathrm{C}$ & $\mathrm{C}$ & $\mathrm{C}$ & $\mathrm{C}$ & $\mathrm{C}$ & $\mathbf{C}$ \\
\hline $\begin{array}{l}\text { Poslodavac stalno vodi evidenciju o } \\
\text { zdravstvenim pregledima radnika. }\end{array}$ & C & $\mathrm{C}$ & $\mathrm{C}$ & $\mathrm{C}$ & $\mathrm{C}$ & $\mathrm{C}$ & $\mathrm{C}$ & $\mathrm{C}$ & $\mathrm{C}$ & C & $\mathrm{C}$ & C \\
\hline $\begin{array}{l}\text { Poslodavac trajno čuva dokumentaciju koja } \\
\text { se odnosi na nezgode na radu i na kolektivne } \\
\text { nezgode. }\end{array}$ & $\mathrm{C}$ & C & C & $\mathrm{C}$ & $\mathrm{C}$ & $\mathrm{C}$ & $\mathrm{C}$ & $\mathrm{C}$ & $\mathrm{C}$ & $\mathrm{C}$ & $\mathrm{C}$ & $\mathrm{C}$ \\
\hline $\begin{array}{l}\text { Poslodavac stalno vodi evidenciju o opasnim } \\
\text { pojavama. }\end{array}$ & C & C & $\mathrm{C}$ & $\mathrm{C}$ & $\mathrm{C}$ & $\mathrm{C}$ & $\mathrm{C}$ & $\mathrm{C}$ & $\mathrm{C}$ & $\mathrm{C}$ & $\mathrm{C}$ & C \\
\hline $\begin{array}{l}\text { Poslodavac stalno vodi evidenciju o } \\
\text { profesionalnim bolestima te bolestima } \\
\text { povezanima s radom i njihovim uzrocima. }\end{array}$ & $\mathrm{C}$ & $\mathrm{C}$ & $\mathrm{C}$ & $\mathrm{C}$ & $\mathrm{C}$ & $\mathrm{C}$ & $\mathrm{C}$ & $\mathrm{C}$ & $\mathrm{C}$ & $\mathrm{C}$ & $\mathrm{C}$ & C \\
\hline $\begin{array}{l}\text { Poslodavac trajno vodi evidenciju o opasnim } \\
\text { tvarima koje upotrebljava. }\end{array}$ & C & C & $\mathrm{C}$ & $\mathrm{C}$ & $\mathrm{C}$ & $\mathrm{C}$ & C & $\mathrm{C}$ & $\mathrm{C}$ & $\mathrm{C}$ & $\mathrm{C}$ & $\boldsymbol{C}$ \\
\hline
\end{tabular}




\section{LITERATURA}

Ahonen, G., Hussi, T.: Economics in occupational health and safety, African Newsletter, 22, 2012., 1, 4-5.

Alteren, A., Hovden, J.: The safety element method: a user developed tool for improvement of safety management, Safety Science Monitor, 2, 1998., 3, 1-23.

Bernard, C. I.: The function of executive, Cambridge (Mass.), Harvard University Press, 2001.

Buhai, S. I., Cottini, E., Westergård-Nielsen, N.: The impact of work health and safety conditions on firm performance: Empirical evidence from Denmark, Tinbergen Institute Discussion Paper 08-13, University of Aarhus, Aarhus School of Business, Department of Economics, 2013.

Cambon, J., Guarnieri, F.: Maitriser les defailances des organisations en sante et securite au travail: La methode Tripod, Notes de synthese et de recherche, Lavoisier, France, 2008.

Cronbach, L. J.: Coefficient Alpha and the internal structure of tests, Psychometrika, 16, 1951., 3, 297-334.

Directive 89/391/EEC - OSH »Framework directive " of 12 June 1989 on the introduction of measures to encourage improvements in the safety and health of workers at work, dostupno na: https://osha.europa.eu/sl/legislation/directives/the-osh-framework-directive/1, pristupljeno: 2. 4. 2017.

De Greef, M., Van den Broek, K.: Making the case of workplace health promotion: Analysis of effects of WHP, Prevent, NCO Belgium, BrusseIs, 2004.

De Waal, A. A.: The secret of high performance organizations, dostupno na: http://www. andredewaal.eu/pdf2008/MORE2008.pdf, pristupljeno: 11. 3. 2017.

Doidge, J. P.: Successful health and safety management, Perfusion, 12, 1997., 4, 217-220.

Drucker, P. F.: Management science' ${ }^{\prime}$ and the manager, Management Science, 1, 1995., 2, 115-126.
Duijm, N. J., Fievez, C., Gerbec, M., Hauptmanns, U., Konstandinidou, M.: Management of health, safety and environment in process industry, Safety Science, 46, 2008., 6, 908-920.

EASHW - European Agency for Safety and Health at Work.: Management of occupational safety and health, An analysis of the findings of the European survey of enterprises on new and emerging risks (ESENER), Luxembourg, Publications Office of the European Union, 2012.

EAVZD - Evropska agencija za varnost in zdravje pri delu.: Oblikovanje varnejšega, bolj zdravega in produktivnejšega evropskega delovnega okolja, dostupno na: https://osha.europa. eu/sl/publications/corporate/EU-OSHA_Corporate_Brochure_2014, pristupljeno: 21. 1. 2017.

EC - European Commission.: Causes and circumstances of accidents at work in the EU, Luxembourg, Office for Official Publications of the European Communities, 2009.

EU - European Union.: Uredba (ES) št. 1338/2008 o statističnih podatkih Skupnosti v zvezi z javnim zdravjem ter zdravjem in varnostjo pri delu, dostupno na: http://www.stat. si/doc/sosvet/Sosvet_26/Sos26_s1144-2009.pdf, pristupljeno: 6. 1. 2017.

Fayol, H.: General and industrial management, Pitman, London, 1949.

Fernández-Muńiz, B., Montes-Peón, J. M., Vázquez-Ordás, J. C.: Relation between occupational safety management and firm performance, Safety Science, 47, 2009., 7, 980-991.

Finlan, G., Roberts, M.: SHE auditing and inspection, dostupno na: http://www.stfc.ac.uk/ she/resources/pdf/sc30.pdf, pristupljeno: 30. 9. 2016.

Gallagher, C., Underhill, E., Rimmer, M.: OHS management systems review of effectiveness in securing healthy and safe workplaces, Sydney, National Occupational Health and Safety Commission, 2001.

Greigle, S. J.: 58 metric safety management system audit, dostupno na: http://www.oshatrain.org/pdf/sharpauditsample.pdf, pristupljeno: 12. 8. 2016. 
Hämäläinen, P., Saarela, K. L., Takala, J.: Global trend according to estimated number of occupational accidents and fatal work-related diseases at region and country level, Journal of Safety Research, 40, 2009., 2, 125-139.

Heinrich, H. W.: Industrial accident prevention: A scientific approach, New York, McGrawHill, 1959.

Huang, Y. H., Leamon, T. B., Courtney, T. K., Chen, P. Y., De'Armond, S.: Corporate financial decision-makers perceptions of workplace safety, Accident Analysis and Prevention, 39, 2007., 4, 767-775.

Jarle, E., Mearns, K., Larsson, G., Laberg, J. C., Johnsen, B. H.: Leadership, psychological capital and safety research: Conceptual issues and future research questions, Safety Science, 50, 2012., 1, 55-61.

Jeffries, F. L.: Predicting safety related attitudes in the workplace: The influence of moral maturity and emotional intelligence, Institute of Behavioral and Applied Management, 12, 2011. 3, 200-216.

Kalčič, M., Lozar, A.: Zakon o varnosti in zdravju pri delu, Ljubljana, GV Založba, 2011.

Keebe, J. J., Topilol, S., Berkeley, S.: Using indicators to measure sustainability performance at a corporate and project level, Journal of Business Ethics, 44, 2003., 2-3, 149-158.

Krause, R. T.: Influencing the behavior of senior leadership: What makes a great safety leader?, Professional Safety, 49, 2004., 6, 29-33.

Markič, M.: Ocenjevanje kakovosti sistema varstva pri delu, zdravstvenega varstva in delovnega okolja, Delo in varnost, 38, 1993., 3, 118-126.

Markič, M., Kolenc, I., Miklavčič Šumanski, M., Živković, S. B.: Vodeći menadžeri i preventivne mjere sigurnosti, Sigurnost, 53, 2011., 4, 319-329.

Milgate, N., Innes, E., O'Loughlin, K.: Examining the effectiveness of health and safety committees and representatives: A review, Work: Journal of Prevention, Assessment and Rehabilitation, 19, 2002., 3, 281-290.
Morse, T., Bracker, A., Warren, N., Goyzueta, J., Cook, M.: Characteristics of effective health and safety committees: Survey results, American Journal of Industrial Medicine, 56, 2013., 2, 163-179.

Podgorski, D.: Measuring operational performance of $\mathrm{OSH}$ management system - A demonstration of AHP - based selection of leading key performance indicators, Safety Science, 73, 2015., 2, 146-166.

Redinger, C. F., Levine, S. P.: Development and evaluation of the Michigan occupational health and safety management system assessment instrument: a universal OHSMS performance measurement tool, American Industrial Hygiene Association Journal, 59, 1998., 8, 572-581.

Robson, S. L., Clarke, A. J., Cullen, K., Bielecky, A., Severin, C., Bigelow, L. P., Irvin, E., Culyer, A., Mahood, Q.: The effectiveness of occupational health and safety management systems interventions: a systematic review, Safety Science, 45, 2007., 3, 329-353.

Roy, M., Desmarais, L., Cadieux, J.: Amelioer la performance en SST: les resultas vs les predictuers. Perspectives indisciplinaries sur la travail et la sante, 7(2), dostupno na: http://www. pistes.uquam.ca/v7n2/articles/v7n2a10.htm, pristupljeno: 5. 4. 2017.

Øien, K., Utne, I. B., Herrera, I. A.: Building Safety Indicators: Pat 1 - Theoretical foundation, Safety Science, 49, 2011., 2, 148-161.

Schumacker, R. E., Lomax, R. G.: A beginner's guide to structural equation modelling, Mahwah, Lawrence Erlbaum Associates, 2004.

Šarotar Žižek, S., Mulej, M.: Creating a healthy company by occupational health promotion as a part of social responsibility, Kybernetes, 45, 2016., 2, 223-243.

Takala, J., Hamalainen, P., Saarela, K. L., Yun, L. Y., Manickam, K., Jin, T. W., Heng, P., Tjong, C., Kheng, L. G., Lim, S., Lin, G. S.: Global estimates of the burden of injury and illness at work in 2012, Journal of Occupational and Environmental Hygiene, 11, 2014., 5, 326-337.

Takala, J., Urrutia, M., Hämäläinen, P., Saarela, K. L.: The global and European work 
environment - numbers, trends, and strategies, Scandinavian Journal of Work, Environment \& Health, Supplements, 2009., 7, 15-23.

Thanwadee, C.: A safety assessment approach using safety enablers and results, International Journal of Occupational Safety and Ergonomics, 18, 2012., 3, 343-361.

Vivek, V., Khanzode, J., Maiti, J., Ray, P. K.: Occupational injury and accident research: A comprehensive review, Safety Science, 50, 2012., 5, 1355-1367.

WSHI - Workplace Safety \& Health Institute.: Global estimates of occupational accidents and work-related illness 2014, dostupno na: https:// www.wsh-institute.sg/files/wshi/upload/cms/ file/Global\%20Estimates\%20of\%20Occupational\%20Accidents $\% 20$ and $\% 20$ Work-related $\% 20$ Illness\%202014.pdf, pristupljeno: 1. 2. 2017.

Yassi, A. K., Lockhart, M., Sykes, M., Buck, B., Stime, B., Spiegel, J. M.: Effectiveness of joint health and safety committees: A realist review, American Journal of Industrial Medicine, 56, 2013., 4, 424-438.

Zakon o varnosti in zdravju pri delu (ZVZD), dostupno na: http://www.pisrs.si/Pis.web/ pregledPredpisa?id=ZAKO1643, pristupljeno: 4. 4. 2017.

\section{THE INSTRUMENT MEASURING THE LEVEL} OF OCCUPATIONAL SAFETY AND HEALTH

SUMMARY: In order to effectively implement the desired vision of zero injuries and work-related health problems, the system of occupational safety and health (OSH) at work needs to focus effectively on planning, organizing, leading and controlling. The purpose of this paper is to present the design and verification of a comprehensive measuring instrument for determining the level of implemented occupational safety and health in an organization. Such a measuring instrument was introduced to assess the level of OSH in 137 large and medium-sized Slovenian business enterprises. This measuring instrument provides a comprehensive insight into the interconnections between the OSH management, working conditions and economic efficiency in an organization. The main finding of the study was that the scope of the OSH management functions can be considered with regard to the following three aspects: organization and operation of the OSH management, documentation of procedures, and regular monitoring of the implementation of $\mathrm{OSH}$ measures. The measuring instrument presents an original and useful tool for various experts: for policy makers in the field of OSH at national level, for business owners and managers, for employees and their representatives, as well as for OSH professional staff in an enterprise or institution.

Key words: enterprise, level of development, management, measurement, measuring instrument, occupational safety and health, research 